\title{
RELIGIOSITY AND FASHION BEHAVIOR AMONG INDONESIAN MUSLIM WOMEN
}

\author{
Listyorini Sari, Kusumawati Andriani*, Suharyono, Yulianto Edy \\ Faculty of Administrative Science, University of Brawijaya, Indonesia \\ ${ }^{*}$ E-mail: andriani kusuma@ub.ac.id
}

\begin{abstract}
Religiosity affects individuals in taking decisions and behaving. The decisions taken are related to purchase of Muslim fashion products. Individuals will feel convinced to purchase fashion products if they are involved in the search of fashion products. The study aimed to investigate whether religiosity and fashion involvement had effect on fashion knowledge and Muslim fashion product customer satisfaction. Data collection was done using questionnaires on 243 female customers in Indonesia. The data were analyzed using WarpLS 5.0. Religiosity and fashion involvement had effect on customer satisfaction without having to go through fashion knowledge. The implication of the study was to give guidance for Muslim fashion product stores to pay attention to elements related to religiosity and to improve the attractiveness of the products and stores to create customer satisfaction.
\end{abstract}

\section{KEY WORDS}

Religiosity, fashion involvement, fashion knowledge, customer satisfaction, Indonesia.

Islam has become an issue in business trade because the sustainability of business without paying attention to Islam market will be threatened (Morphitou and Gibbs, 2004). The aim of Islam market is in line with sharia goals where humans are the messengers of Allah so their behaviors are controlled according to the will of Allah (Khan, 1991; Haneef, 1997; Hassan and Lewis, 2007). Therefore, according to Sandikci (2011), Muslim market segment is a potential to attract marketers in Islam marketing concept. The characteristics of Muslim customer depend on religious values and the characteristics of purchase depend on their religious belief (Alserhan, 2010). Regional marketers who try to enlarge their business to Muslim market overall are understanding about the basis of customer needs (Hanzaee and Chitsaz, 2011). One of customer needs is obeying their religion that is a part of the culture. However, religion is not like other cultural dimensions, religion tends to be stable and static (Farrag and Hassan, 2015). As marketers, guarantee that the tendency of religion to be static can be controlled (Fam et al., 2004). Muslim products have opportunities to control the tendency because they involve religion as the reference.

Religiosity is a part of religion as someone's faith to God and obeying the religion (McDaniel and Burnettm 1990, Weaver and Agle, 2002). Religiosity plays a great role in purchase approach, opinion on price, and product quality (Reitsma, Scheepers, \& Grotenhuis, 2006; Yousaf \& Malik, 2012; Rehman \& Shabbir, 2010; Khraim, 2010). Among Muslim customers, religiosity is one of the factors affecting the attitude towards innovation (Rehman \& Shabbir, 2010; Azam A. Qiang, Abdullah, \& Abbas, 2011; Ansari, 2014). Religion is considered an important factor to test customer behavior (Al-Hyari, Alnsour, Al-Weshah, \& Haffar, 2012; Bachleda, Hamelin, \& Benachour, 2014; Essoo \& Dibb, 2004; Alhaija et al.,2018), and give important guidance to understand attitude and behavior (Minton, Kahle, \& Kim, 2015).

Humans highly depend on fashion, so the existence of fashion is crucial (Woodward, 2007). The needs to give respond to fashion can be seen when someone needs any fashion elements that can highlight his/her self-esteem (Ahmad, Iqbal, Jjaved, 2014). Fashion that always changes will be useful for studies on customer behavior (Eicher and Roach-Higgins, 1992). Fashion determines someone's self-esteem so manufacturers have to be creative to satisfy the needs, one of them is fashion products for Muslim women. According to Gooch (2011), fashion for Muslim women is outfit that covers from head to ankle. In meeting Islamic fashion, it is not only to cover the aurat, but also to meet the principles of closed dress. 
Therefore, in taking decision of selection of Muslim fashion products, customers need to be involved more deeply in finding information of Muslim fashion products. According to Mowen and Minnor (2002), customers have different involvement in deciding purchase that depends on individual, purchase objects, time, and place of purchase. Fashion involvement is related to individual behavior related to their fashion style including knowledge, awareness, interest, and reaction on selecting their clothes (O'Cass, 2004).

High involvement will cause customer interest to keep looking for information. Products with high involvement will have great value felt by customers. Fashion knowledge is developed when customers combine separate concepts of fashion (O'Cass, 2004). Subjective knowledge level of customers about products (familiarity, experience, and skills) is affected by involvement level in clothes. Measuring product knowledge by how many customers really know the products and how many customers think or feel that they know the products.

Customer satisfaction will occur if the products purchased are in accordance with their expectation. Kotler (2003) states that the concept of customer satisfaction is abstract and the real satisfaction expression. Satisfaction levels differ depending on how customers compare products and services of the company. High or low level of religiosity will determine how low or high the level of involvement is in finding fashion products therefore customer satisfaction is made to determine whether there is satisfaction on fashion products selected based on the brands and products.

Indonesia becomes quite potential Muslim fashion market showed by the increase of export of this business. The business produces foreign currency with export value of USD 8.2 billion since July 2018 or increasing for $8.7 \%$ annually. Based on the data from Statistics Indonesia, fashion sector is one of the main contributors to Gross Domestic Products (GDP) of creative economy in 2016 for $18.01 \%$ or equal to IDR 166 trillion (www.katadata.co.id). The phenomenon gives positive value for Muslim fashion businessmen in Indonesia. However, the fact becomes a challenge to produce Muslim fashion that is not contradictory to Islamic rules. Female customers generally want to always look beautiful and fashionable in dress so the need can be captured by marketers. Marketers want to satisfy the need, but also take religiosity values in developing the business.

\section{LITERATURE REVIEW}

Fashion Behavior. Sproles (1974) states that the phenomenon of dress behavior has become an interesting topic for social analysts, cultural historians, moral critics, businessmen, and academicians. From the perspective of academicians, King et al. (1979) argues that customers are the agent of fashion change because they monitor fashion development so that their dress style keeps up to date in accordance with fashion trend. Customer behavior on fashion has affected some aspects of fashion industry such as design, production, merchandising, and promotion, where the aspects affect retail industry. In fashion industry, the only constant thing is fashion change, it means that fashion trend always develops and never stops. It also applies to Muslim fashion that always follows the development.

Religiosity. Religiosity is crucial in human life. The realization of religiosity is when someone worships or performs other activities supported by supernatural force. Religion requires everyone to follow certain life style and affects their beliefs and values including dress habit. Religiosity is defined as how far someone is committed to the religion and recognizes the teachings such as attitudes and behaviors that are the reflection of the commitment (Johnson et al., 2001). The level of religiosity becomes the main determiner of attitude and behavior of Muslim customers (Souiden \& Rani, 2015).

According to Maclean, Walker, and Matsuba (2004), transmission of religious values and how religion forms a part of self-identity. Tan and Vogel (2008) state that religiosity is how far someone takes beliefs, experiences, and religious rituals.

Fashion Involvement. Involvement has played important role in literatures about marketing. Fashion involvement affects customer emotion when shopping (Parket et al., 
2006) and positively affects impulsive purchase. Fashion involvement can increase tendency for impulsive purchase of products oriented to fashion (Han et al., 1991; Park et al., 2006).

According to Engel et al. (2005), fashion involvement is defined as "customer interest in fashion or personal relevance perceived". Customer involvement in products depends on the capacity of the products in satisfying customer expectation and trust (Zaichkowsky, 1985). According to O'Cass (2000), the more costumers get involved in fashion, the more they get involved in purchasing fashion.

Fashion Knowledge. Fashion knowledge is a form of knowledge with 4 interrelated things, namely fashion on media that affects customer preference for certain style. Secondly, fashion in local community where fashion ideas spread by personal interactions related to social status. Thirdly, fashion is expressed in clothes through design quality and makes clothes have social meaning. However, the meaning delivered is not stable and can change in accordance with fashion trend. Fourthly, fashion is expressed by companies through brands.

O'Cass (2004) states that knowledge is product familiarity or prior knowledge about object or stimulus. In context of fashion, product knowledge is considered as familiarity with product class brand and product use attribute, usage frequency, and experience with fashion (Raju and Reilly, 1979; Johnson and Russo, 1984).

Customer Satisfaction. According to Kotler (2000), customer satisfaction level is assessed by comparing product/service perception in connection with customer expectation. Customer satisfaction is defined as overall attitude on service providers or emotional reaction on difference between what the customers expect and what they receive. Oliver (1997) defines satisfaction/dissatisfaction as "the response to customer satisfaction, to which extent the fulfillment is pleasing or not". It involves "evaluative, affective, or emotional response".

\section{METHODS OF RESEARCH}

Research Model. Muslim fashion retailers want to know how religiosity and fashion involvement can cause fashion knowledge and eventually results in customer satisfaction. Prior studies were done by Johana and Putit (2015), Bhaduri et al., (2016), Eid and ElGohary (2015), Afonso (2009), Bianchi (2015), Islam (2011).

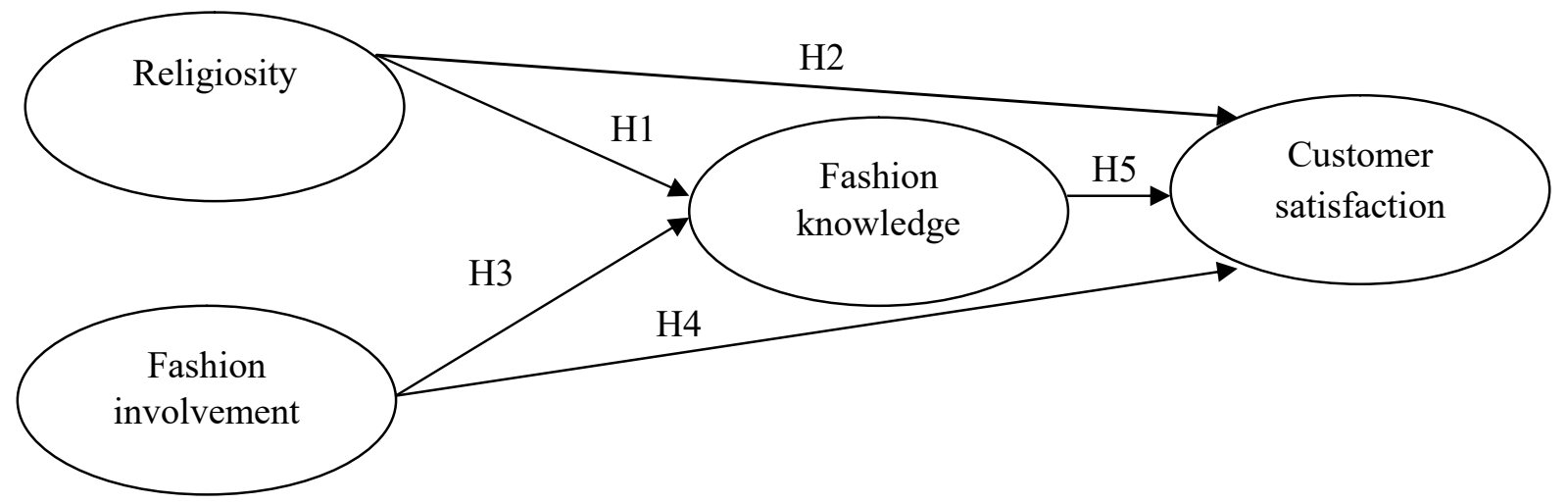

Figure 1 - Hypothesis Model

Correlation between religiosity and fashion knowledge. Wilson (2011), mostly the behavior of Muslim customers is a part of culture that requires marketers to understand Islam through various lenses of Muslim customers. The condition will direct to more specific customer classification to facilitate product knowledge. Empirical study regarding the correlation is shown by Johana and Putit (2015) that investigated the effect of knowledge on religiosity Islamic credit card compliance. The result shows that knowledge and religiosity had significant effect on Islamic credit card compliance. Muslims will realize prohibition from consuming a product or service when they are faced by their religious commitment, so they need to know products certainly. Based on the theory, the first hypothesis of the study was: 
$\mathrm{H1}$ : Religiosity has effect on fashion knowledge.

The correlation between religiosity and customer satisfaction. Global markets attempts to understand religious principles because they are the source of decision making (Khraim, 2010; Layton et al., 2011). Different levels of religious compliance of individuals result in different behaviors in choosing at market and obligation to brands (Rindfleisch et al., 2005; Khraim, 2010). Religious people surely follow their religious principles such as worship regularity, strong commitment, and on the contrary if the principles are weak, they will behave freely (Mokhlis and Spartks, 2007).Therefore, the stronger someone holds his/her religious principles, he/she will behave in accordance with the commitment. If they behave in accordance with the commitment, it will result in individual satisfaction. Based on the theory, the first hypothesis of the study was:

$\mathrm{H} 2$ : Religiosity has effect on customer satisfaction.

Correlation between fashion involvement and fashion knowledge. Those who have high experience with interest in product categories that direct to high product knowledge (O'Cass, 2004). Costumers highly involved make their time to find information because they evaluate various sources (Assael, 1998). The result of study by Bhaduri and Stanforth (2016) on American women regarding fashion involvement and fashion knowledge is that fashion involvement positively affected knowledge of fashion. Based on the theory, the first hypothesis of the study was:

H3: Fashion involvement has effect on fashion knowledge.

Correlation between fashion involvement and customer satisfaction. Customer involvement affects the level of customer satisfaction, it is caused by the effect of customer evaluation before using a product and after using the product (Shaffer and Sherrel, 1997). Someone with high involvement will evaluate products and have expectation to the products that aim to right purchase decision (Bolfing and Woodruff, 1988; Oliver and Bearden, 1983 in Shaffer and Sherrell, 1997).Based on the theory, the first hypothesis of the study was:

$\mathrm{H} 4$ : Fashion involvement has effect on customer satisfaction.

Correlation between fashion knowledge and customer satisfaction. Kotler (2000) argues that satisfaction refers to happy or disappointed feelings of someone due to a product's performance in connection with his/her expectation. A study by Islam et al. (2011) regarding the effect of knowledge on satisfaction at mode house and brand shop has a result that knowledge has significant positive correlation with customer satisfaction. By relying on customer knowledge, customers will be satisfied by a product based on the result of his/her knowledge. Based on the theory, the first hypothesis of the study was:

$\mathrm{H} 5$ : Fashion knowledge has effect on customer satisfaction.

\section{METHODS OF RESEARCH}

Survey Instrument. The study consists of 4 variables, namely religiosity, fashion involvement, fashion knowledge, and customer satisfaction. The number of overall items to measure exogenous and endogenous variables is 25 items. Religiosity consists of 11 items, fashion involvement consists of 6 items. Fashion knowledge and customer satisfaction respectively consist of 4 items. The study used 5-point Likert scale from 1 ("Strongly Disagree") to 5 ("Strongly Agree"). Demography description of the study includes age, status, job, and spending for fashion.

Sample. Population of the study was female customers who had bought Muslim fashion products at Muslim fashion stores in Yogyakarta and Semarang, Indonesia. Sampling technique used purposive sampling. Sample characteristics used were (1) Muslim fashion store visitors who had bought the products twice within the last 6 months; (2) minimum age of 18 years old; (3) buyers and users of Muslim fashion products; (4) active in attending religious events or becoming a religious member.

Data analysis. To analyze the data of the study used WarpLS 5.0 to test the effect of religiosity and fashion involvement on fashion knowledge and customer satisfaction. According to Hair, Ringle, and Sarstedt (2011), PLS was based on prediction of endogenous latent variables. PLS offered acceptable results for measurement model. The data used in 
PLS SEM did not need to meet the requirements of data normality assumption; therefore PLS-SEM gave allowance to non-normally distributed data.

\section{RESULTS OF STUDY}

Respondent profile. The age of respondents in the study was mostly 21 years old $(24 \%)$, the status of respondents was mostly single $(48.9 \%)$, the job of respondents was mostly students $(67 \%)$, the highest level of education was mostly senior high school $(56.8 \%)$, the spending for fashion was mostly IDR 500,000 (18.9\%).

Construct validity, dimensionality, and reliability. Based on the analysis, loading factor of overall indicators used to measure 4 variables (Religiosity, Fashion Involvement, Fashion Knowledge, and Customer Satisfaction) $<0.60$ so it could be said as reliable. According to Nunally (1996) in Imam Ghozali (2001), a list of questions can be said as reliable if they have Cronbach Alpha >0.6.

The Cronbach Alpha value obtained from the study ranged from 0.726 to 0.911 . The Cronbach Alpha value in the study used value of 0.6 with assumption that the questionnaire instrument tested was said as reliable when the Cronbach Alpha value $\geq 0.6$ (Nunally (1996) in Imam Ghozali (2001)). In addition, the average variance extracted (AVE) from the four constructs ranged from 0.509 to 0.860 , which significantly exceeded the acceptable minimum value of 0.5 (Fornell and Larcker, 1981). According to Fornell and Larcker (1981), if AVE is less than 0.5 but has composite reliability more than 0.6 , it will still meet the validity requirement. The value is shown in Table 1 . It can be concluded that the instrument of the study was valid and reliable.

Model Analysis. The first model was presented directly from religiosity on fashion knowledge, religiosity on customer satisfaction, fashion involvement on fashion knowledge, fashion involvement on customer satisfaction, fashion knowledge on customer satisfaction. The first stage was testing the model whether it was developed accordingly or not by observing the fit model. The following is the result: Average path coefficient $(A P C)=0.268$, $P<0.001$, Average R-squared (ARS) $=0.367, \quad P<0.001$, Average adjusted R-squared (AARS) $=0.360, P<0.001$, Average block VIF $($ AVIF $)=1.436$, acceptable if $<=5$, ideally $<=3.3$, Average full collinearity VIF (AFVIF) $=1.691$, acceptable if $<=5$, ideally $<=3.3$, Tenenhaus GoF $(\mathrm{GoF})=0.459$, small $>=0.1$, medium $>=0.25$, large $>=0.36$, Sympson's paradox ratio $(S P R)=1.000$, acceptable if $>=0.7$, ideally $=1, R$-squared contribution ratio $(R S C R)=1.000$, acceptable if $>=0.9$, ideally $=1$, Statistical suppression ratio $(S S R)=1.000$, acceptable if $>=$ 0.7 , Nonlinear bivariate causality direction ratio $(\mathrm{NLBCDR})=1.000$, acceptable if $>=0.7$. Based on the criteria mentioned, the model of the study met the requirements of fitness.

Table 1 - Cronbach Alpha's Value, CR, and AVE

\begin{tabular}{|c|c|c|c|}
\hline Variable & $\alpha$ coefficients & CR & AVE \\
\hline Religiosity & 0.911 & 0.925 & 0.531 \\
\hline Fashion Involvement & 0.862 & 0.898 & 0.598 \\
\hline Fashion Knowledge & 0.726 & 0.831 & 0.860 \\
\hline Customer Satisfaction & 0.782 & 0.860 & 0.561 \\
\hline
\end{tabular}

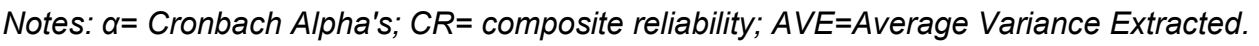

Table 2 shows the coefficient path of each track. After data analysis was done, the result indicating whether the hypotheses were accepted or rejected was found. $\mathrm{H} 1$ stating that religiosity had effect on fashion knowledge was rejected $(\alpha=0.090 ; p=0.08), H 2$ stating that religiosity had effect on customer satisfaction was accepted $(\alpha=0.189 ; p<0.001), H 3$ stating that fashion involvement had effect on fashion knowledge was accepted $(\alpha=682 ; p<$ 0.001 ), $\mathrm{H} 4$ stating that fashion involvement had effect on customer satisfaction was accepted $(\alpha=0.321 ; p<0.001)$. H5 stating that fashion knowledge had effect on customer satisfaction was rejected $(\alpha=0.057 ; p<0.19)$.

Figure 2 presents the result of study regarding correlation between religiosity and fashion involvement on customer satisfaction through fashion knowledge. Overall variable 
correlation affected $p<0.01$ (religiosity on customer satisfaction, fashion involvement on fashion knowledge, fashion involvement on customer satisfaction). There were two noninfluential correlation, religiosity on fashion knowledge and fashion knowledge on customer satisfaction.

Table 2 - Significance Testing Results of the Structural Model Path Coefficient

\begin{tabular}{ccccc}
\hline Hypothesis & Path & Path coefficient & Significance Level & P-Values \\
\hline H1 & Religiosity $\rightarrow$ Fashion Knowledge & 0.090 & NS & 0.08 \\
H2 & Religiosity $\rightarrow$ Customer Satisfaction & 0.189 & $* * *$ & $<0.001$ \\
H3 & Fashion Involvement $\rightarrow$ Fashion Knowledge & 0.682 & $* * *$ & $<0.001$ \\
H4 & Fashion Involvement $\rightarrow$ Customer Satisfaction & 0.321 & $* * *$ & $<0.001$ \\
H5 & Fashion Kowledge $\rightarrow$ Customer Satisfaction & 0.057 & NS & 0.19 \\
\hline
\end{tabular}

${ }^{* *} p<0.01$, NS : Not Significance.

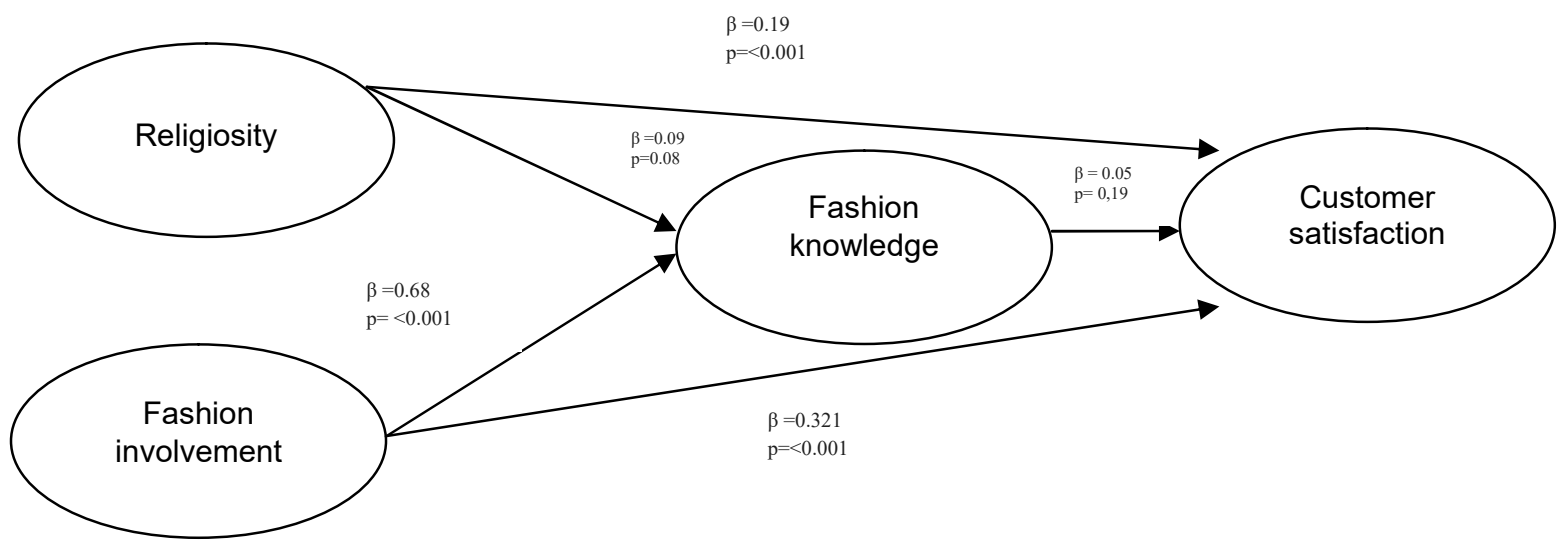

Figure - 2 Research Findings

\section{DISCUSSION OF RESULTS}

The result of study shows that religiosity did not have any effect on fashion knowledge. The result did not support the study by Johana and Putit (2015). Wilson (2011) states that if customers are classified by their religions specifically, it will be easy to know their needs based on their religions. Therefore, customers will purchase if they have known information on the product to be purchased. The study shows that customer religiosity was high because they understood the regulations set in their religion so the knowledge of fashion is an obligation for individuals with high religiosity.

The study also found that religiosity had effect on customer satisfaction. The result supported the opinion of Rindfleisch et al., 2005; Khraim, 2010; Mokhlis and Spartks, 2007, that religious people would be commited to their religion so it will be adjusted to their behavior and decision making. The behavior compliance will result in personal satisfaction for individuals.

The research finding on influential correlation also applied to the correlation between fashion involvement on fashion knowledge that supported the study by Bhaduri and Stanforth (2016). Customers highly involved make their time to find information because they evaluate various sources (Assael, 1998).

Another finding of the study was that fashion involvement had effect on customer satisfaction. It supported the opinion of Bolfing and Woodruff, 1988; Oliver and Bearden, 1983 in Shaffer and Sherrell, 1997, where someone with high involvement will evaluate products and have expectation towards the products that direct to right and satisfying purchase decision.

Furthermore, the study found that fashion knowledge did not have any effect on customer satisfaction. The result of study did not support the study by Islam et al. (2011). By relying on customers' knowledge, customers will be satisfied by a product based on the 
result of the knowledge. In the study, it was confirmed that fashion knowledge was not a factor causing customer satisfaction in purchasing Muslim fashion products. Religiosity and fashion involvement of customers could directly affect customer satisfaction. Customers consider Muslim fashion as their obligation in implementing Islamic sharia, so their knowledge as Muslim women is an obligation as individuals who hold religiosity strongly.

\section{CONCLUSION}

The study aimed to investigate the effect of religiosity and fashion involvement on fashion knowledge and customer satisfaction in purchasing Muslim fashion products. Based on previous review, not many studied the correlation between religiosity and fashion knowledge in Muslim fashion retail sector specifically. Preliminary studies found the existence or non-existence of effect of religiosity and fashion knowledge, fashion involvement and fashion knowledge, religiosity and fashion involvement on customer satisfaction. The data analysis used WarpLS 5.0 to achieve the aims of the study.

The mediation in the study was fashion knowledge that mediates the correlation between religiosity and fashion involvement on customer satisfaction. The study suggested a model of indirect correlation of religiosity and fashion knowledge on customer satisfaction. Based on the result of testing of hypotheses, it was found that there was no effect of religiosity on fashion knowledge. The second finding, religiosity had effect on fashion knowledge. Thirdly, fashion involvement had effect on fashion knowledge. Fourthly, fashion involvement had effect on customer satisfaction. Fifthly, fashion knowledge did not have any effect on customer satisfaction. The conclusion shows that fashion knowledge was not a mediation variable between religiosity and fashion involvement on customer satisfaction. Religiosity and fashion involvement had direct effect on customer satisfaction without having to be mediated by fashion knowledge.

Practical implication. The practical implication of the study was to improve the quality of Muslim fashion products so as to satisfy customers on the products. The study shows that without having to go through fashion knowledge first, customers with high religiosity and high fashion involvement will be directly satisfied by Muslim fashion products. For Muslim fashion stores, in addition to improve the product quality directly related to religiosity, also need to pay attention to other attributes such as the hospitality of shopkeepers. For customers, it is important to pay attention to products and evaluate them before purchasing because the products are considered religious.

Research limitations and directions for future research. The research limitation is that it only included female samples in which the characteristics could have been different is it included male too. Secondly, the area was only 2 cities in Indonesia.

To improve the research contribution, it is expected that future researchers will be able to use male samples for Muslim fashion product purchase and enlarge the research area spread in Indonesia.

\section{REFERENCES}

1. Ahmad Saif-Alddin Abu-Alhaija, Raja Nerina Raja Yusof, Haslinda Hashim, Nor Siah Jaharuddin. 2018. Religion in Consumer Behaviour Research: the Significance of Religious Commitment and Religious Affiliation, International Journal of Economics, Commerce and Management, Vol. VI, Issue 1, January 2018, ISSN 23480386

2. Al-Hyari, K., Alnsour, M., Al-Weshah, G., \& Haffar, M. 2012. Religious beliefs and consumer behaviour: from loyalty to boycotts. Journal of Islamic Marketing, 3(2), 155174. http://doi.org/10.1108/17590831211232564

3. Alserhan, B. A. 2010. On Islamic branding: brands as good deeds. Journal of Islamic Marketing, 1(2), 101-106.

4. Ansari, Z. A. 2014. The Relationship between Religiosity and New Product Adoption among Muslim Consumers. International Journal of Management Sciences, 2(6), 249259. 
5. Assael, H. 1998. Consumer Behavior and Marketing Action, 6th Edition. Cincinatti, Ohio: South Western College Publishing.

6. Azam, A., Qiang, Q. F., Abdullah, M. I., \& Abbas, S. A. 2011. Impact of 5-D of Religiosity on Diffusion Rate of Innovation. International Journal of Business and Social Science, 2(17), 177-185.

7. Bachleda, C., Hamelin, N., \& Benachour, O. 2014. Does religiosity impact Moroccan Muslim women's clothing choice? Journal of Islamic Marketing, 5(2), 210-226. http://doi.org/10.1108/JIMA-05-2013-0038

8. Bhaduri, G. and Stanforth, N. 2016. Evaluation of absolute luxury: effect of cues, consumers' need for uniqueness, product involvement and product knowledge on expected price. Journal of Fashion Marketing and Management: An International Journal

9. Bianchi, C. 2014. Consumer Brand Loyalty in the Chilean Wine Industry. Journal of Food Products Marketing, 00:1-19, 2014, ISSN: 1045-4446 print/1540-4102 online, DOI: 10.1080/10454446.2014.885859

10. Bolfing, C. \& R. B. Woodruff,.1988. An Effect of Situational Involvement on Consumers Use of Standards in Satisfaction/Dissatisfaction Processes, Journal of Consumer Satisfaction, Dissatisfaction and Complaining Behavior, Vol. 1, pp. 16-24.

11. Dalia Abdelrahman Farrag, Mohammed Hassan, 2015. "The influence of religiosity on Egyptian Muslim youths' attitude towards fashion", Journal of Islamic Marketing, Vol. 6 Issue: 1, pp.95-108, https://doi.org/10.1108/JIMA-04-2014-0030

12. Eid, R., H. E.-G. 2015. The role of Islamic religiosity on the relationship between perceived value and tourist satisfaction. Tourism Management , 477-488.

13. Engel, James et al. 2006. Consumer Behaviour. Mason: Permissions Department, Thomson Business and Economics

14. Essoo, N., \& Dibb, S. 2004. Religious influences on shopping behaviour: an exploratory study. Journal of Marketing Management, 683-712.

15. Fam, K.S., Waller, D.S. and Erdogan, B.Z. 2004. "The inluence of religion on attitudes towards the advertising of controversial products", European Journal of Marketing, Vol. 38 Nos 5/6, pp. 537-555.

16. Fornell, C. G., \& Larcker, D. F. 1981. Evaluating structural equation models with unobservable variables and measurement error. Journal of Marketing Research, 18(1), $39-50$

17. Ghozali, Imam, 2001, Aplikasi Analisis Multivariate dengan Program SPSS, Badan Penerbit Universitas Diponegoro, Semarang.

18. Gooch, L. 2011. Finding sales in Islamic wear. The International Herald Tribune, Leisure p. 14. Retrieved April 12, 2012, from LexisNexis Academic.

19. Hair, J.F., Ringle, C.M., Sarstedt, M., 2011. PLS-SEM: indeed a silver bullet, Journal of Marketing Theory and Practice 19 (2), 139e151

20. Han, Y.K., Morgan. G.A., Kotsiopulos, A., \& Kang-Park, J. 1991. Impulsive buying behaviour of apparel purchasers. Clothing and Textiles Research Journal, 9(3):15-21

21. Haneef, M.A.M. 1997. 'Islam, the Islamic worldview, and Islamic economics', IIUM Journal of Economics and Management, Vol. 5, No. 1, pp.39-65.

22. Hariyanti D. 2018. Gaya Busana Muslim Kekuatan Baru Industri Fesyen di Kancah Global. Retrieved from https://katadata.co.id/berita/2018/10/01/

23. Hassan, M.K. and Lewis, M.K. 2007. 'Ends and means in Islamic banking and finance', Review of Islamic Economics, Special Issue, Vol. 11, pp.5-27

24. Islam, M.A Mohammad MR Khan Khadem, Md. Alauddin. 2011. An empirical assessment of the relationship between service quality and customer satisfaction in fashion house, Proceedings of the 2011 International Conference on Industrial Engineering and Operations Management Kuala Lumpur, Malaysia, January 22 - 24, 2011

25. Johana, Z.J., L. P. 2016. Conceptualizing the Influences of Knowledge and Religiosity on Islamic Credit Card Compliance. Fifth International Conference on Marketing and Retailing (5TH INCOMaR) 2015 (hal. 480 - 487). Elsevier. 
26. Johnson, B.R., Jang, S.J., Larson, D.B., \& Li, S.D. 2001. Does adolescent religious commitment matter? A reexamination of the effects of religiosity on delinquency. Journal of Research in Crime and Delinquency, 38(1), 22-44.

27. JOHNSON, E.; RUSSO, J. 1984. Product familiarity and learning new information. Journal of Consumer Research, Gainesville, v.11, n.1, p.542-550.

28. Kambiz Heidarzadeh Hanzaee and Shahrzad Chitsaz. 2011. A review of influencing factors and constructs on the Iranian women's Islamic fashion market, Interdisciplinary Journal of Research in Business, Vol. 1, Issue. 4, April 2011(pp.94-100).

29. Khan, M.A. 1991. 'The future of Islamic economics', Futures, Vol. 23, No. 3, pp.248-261.

30. Khraim, H. 2010. Measuring Religiosity in Consumer Research From an Islamic Perspective. Journal of Economic \& Administrative Sciences, 26(1), 52-78. Retrieed Novemebr Friday, 2019, from http://dx.doi.org/10.1108/10264116201000003

31. King, CW, Ring, L \& Tigert, D.1979, 'Fashion involvement and retail buying behavior: In Competition in retail markets: a department store perspective', Proceedings of the New York University, American Marketing Association Retail Conference.

32. Kotler, P. Marketing Management, 10th ed.; Prentice-Hall: Upper Saddle River, NJ, 2000.

33. Kotler, P. 2003.Marketing Management, 11th Edition.Prentice Hall.Inc.New Jersey. Hal 85.

34. Layton, E., Dollahite, D.C. and Hardy, S.A. 2011. "Anchors of religious commitment in adolescents", Journal of Adolescent Research, Vol. 26 No. 3, pp. 381-413.

35. Liza Nora and Nurul S. Minarti. 2016. The Role Of Religiosity, Lifestyle, Attitude As Determinant Purchase Intention. Proceedings The 2nd International Multidisciplinary Conference November 15th. Universitas Muhammadiyah Jakarta, Indonesia: 135-148 ISBN 978-602-17688-9-1.

36. Maclean, A.M., Lawrence J. Walker, M. Kyle Matsuba. 2004. Transcendence and the Moral Self: Identity Integration, Religion, and Moral Life, Journal for the Scientific Study of Religion 43:3, pp. 429-437.

37. McDaniel SW and Burnett JJ. 1990. Consumer religiosity and retail store evaluative criteria. Journal of the Academy of Marketing Science.18:: 101-112.

38. Minton, E. A., Kahle, L. R., \& Kim, C.-H. 2015. Religion and motives for sustainable behaviors: A cross-cultural comparison and contrast. Journal of Business Research, 68(9), 1-8. http://doi.org/10.1016/j.jbusres.2015.01.003.

39. Mokhlis, S. and Spartks, L. 2007, "Consumer religiosity and shopping behaviour in Kuala Lumpur", Malaysian Management Journal, Vol. 11 No. 1 \& 2, pp. 87-101.

40. Morphitou.R \& Gibbs P.2008. Insights for Consumer Behaviour in Global Marketing: an Islamic and Christian comparison in Cyprus", Retrieved from: www.escpeap.net/conferences/marketing/.../Morphitou_Gibbs.pdf.

41. Mowen, C. and Minor, J.M. 2002. Perilaku Konsumen. Jakarta. Erlangga.

42. Naveed Ahmad, Nadeem Iqbal, Komal Javed. 2014. Impact of Islamic Fashion Marketing on Islamic Marketing: "A Case Study Of Pakistani Women's", Kuwait Chapter of Arabian Journal of Business and Management Review Vol. 3, No.5; Jan. 2014

43. O'Cass, A. 2004. Fashion clothing consumption:antecedents and consequences of fashion clothing involvement. European Journal of Marketing Vol. 38 No. 7.

44. O'Cass, A. 2000. An assessment of consumers' product, purchase decision, advertising and consumption involvement in fashion clothing. Journal of Economic Psychology, v.21, n.5, p.545-576, Summer 2000.

45. Oliver, R.L. 1999. Whence Consumer Loyalty?. Journal of Marketing, vol. 63, Fundamental Issues and Directions for Marketing pp. 33-44.

46. Özlem Sandikci, 2011. "Researching Islamic marketing: past and future perspectives", Journal of Islamic Marketing, Vol. 2 Iss: 3 pp. 246 - 258.

47. Park, E. J., Kim, E. Y., \& Forney, J. C. 2006. A structural model of fashion-oriented impulse buying behavior. Journal of Fashion Marketing and Management, 10(A): 433446.

48. Raju, P. \& Reilly, M. 1979. Product familiarity and information- -processing strategies: an exploratory investigation. Journal of Business Research, v.8, n.2, p.187-212. 
49. Rehman, A. U., \& Shabbir, M. S. 2010. The relationship between religiosity and new product adoption. Journal of Islamic Marketing, 1(1), 63-69. http://dx.doi.org/10.1108/17590831011026231.

50. Reitsma, J., Scheepers, P., \& Grotenhuis, M. T. 2006. Dimensions of Individual Religiosity and Charity: Cross-National Effect Differences in European Countries? Review of Religious Research, 47(4), 347-362. Retrieved from http://www.jstor.org/stable/20058103.

51. Rindfleisch, A., Burroughs, J. E. and Wong, N. 2005. "Religiosity and brand commitment: A multicultural perspective", Asia Pacific Advances in Consumer Research, Vol. 6.

52. Roach-Higgins M. E., Eicher B. J. 1992. Dress and identity. Clothing and Textiles Research Journal 1992: 1-8.

53. Souiden, N., \& Rani, M. 2015. Consumer attitudes and purchase intentions toward Islamic banks: the influence of religiosity. International Journal of Bank Marketing, 33(2), 143-161. http://doi.org/10.1108//JBM-10-2013-0115.

54. Sproles, G.B., 1974. "Fashion Theory: a Conceptual Framework", in NA-Advances in Consumer Research Volume 01, eds. Scott Ward and Peter Wright, Ann Abor, Ml: Association for Consumer Research, Pages: 463-472.

55. T. R. Shaffer and D. L. Sherrell. 1997. "Consumer satisfaction with health-care services: The influence of involvement," Psychology and Marketing, vol. 14, pp. 261-285.

56. Tan, J. H. W. and Vogel, C. 2008. "Religion and trust: An experimental study", Journal of Economic Psychology, Vol. 29 (6): 832-848.

57. Vieira, V. A. 2009. An extended theoretical model of fashion clothing involvement. Journal of Fashion Marketing and Management Vol. 13 No. 2 , 179-200.

58. Weaver, G.R. And Agle, B. 2002. Religiosity and Ethical Behavior in Organizations: A Symbolic Interactionist Perspective. Academy of Management Review, 27, p 77-97.

59. Wilson, J.A, 2011. "The challenges of Islamic branding: navigating emotions and Halal". Journal of Islamic Marketing, 2(1), pg 28-42.

60. Woodward, S. 2007. Why Women Wear What They Wear. Oxford: Berg

61. Yousaf, S., \& Malik, M. S. 2012. Evaluating the influences of religiosity and product involvement level on the consumers. Journal of Islamic Marketing, 4(2), 163-186. http://dx.doi.org/ 10.1108/17590831311329296

62. Zaichkowsky, J.L., 1985. Measuring the involvement construct. Journal of Consumer Research 12,341-352. 